特集 : 最近の膜モジュール

浸漬型セラミック膜処理システムの開発と応用

鳴上善久・塩山昌彦*

株式会社クボタ 新淀川環境プラントセンター † 555 大阪市西淀川区西島 2-1-6

*株式会社クボタ 上下水プラント技術第二部 干 556 大阪市浪速区敷津東1-2-47

\title{
Development and Application of Water and Wastewater Treatment System Using Tank Submerged Type Ceramic Membrane
}

\author{
Yoshihisa Narukami and Masahiko Shioyama \\ KUBOTA Corp., Water \& Sewage Plant Div. \\ 1-2-47 Shikitsuhigashi, Naniwa-ku, Osaka 556, Japan
}

We have developed two systems called BIOREM and FILCERA. BIOREM is combined with activated sludge treatment system and tank submerged type ceramic membrane filtration system. Membrane modules are stacked in the aeration tank, and diffusers in the bottom are cleaning the membrane surface by circulating air bubbles.

The membrane module is bringing together multiple external pressure tubular type ceramic membrane elements of an asymmetric two layer structure. The MLSS is holded about 15,000 $\mathrm{mg} / l$, so aeration tank needs smaller volume and the system can get along without sedimation tank and outside membrane space. The system was authorized by the Minister of Construction. The $100 \mathrm{~m}^{3} / \mathrm{day}$ plant is running now to treat the domestic sewage.

FILCERA is combined with coagulation system and tank submerged type ceramic membrane filtration system for water purification. Becuse there is no need for phsical pretreatment to reduce turbidity, the system is simple and compact. Maintenance is also easy.

Key words : ceramic membrane, tank submerged type, activated sludge, domestic sewage, coagulation, water purification, external pressure tubular type

\section{1.はじめに}

今日の日本をみると水処理産業は上水道は別と して, 静脈型産業から動脈型産業へと変わりつつ
ある.これらの水処理設備に最近膜分離技術が適 用されてきている. 逆浸透膜, 限外万過膜, 精密 ろ過膜を用いた膜分離技術は, 超純水製造, 海水 淡水化, 食品工業, 医薬品工業, 各種排水処理な 
Table 1 Classified list of degradation and fouling of membrane ${ }^{6}$

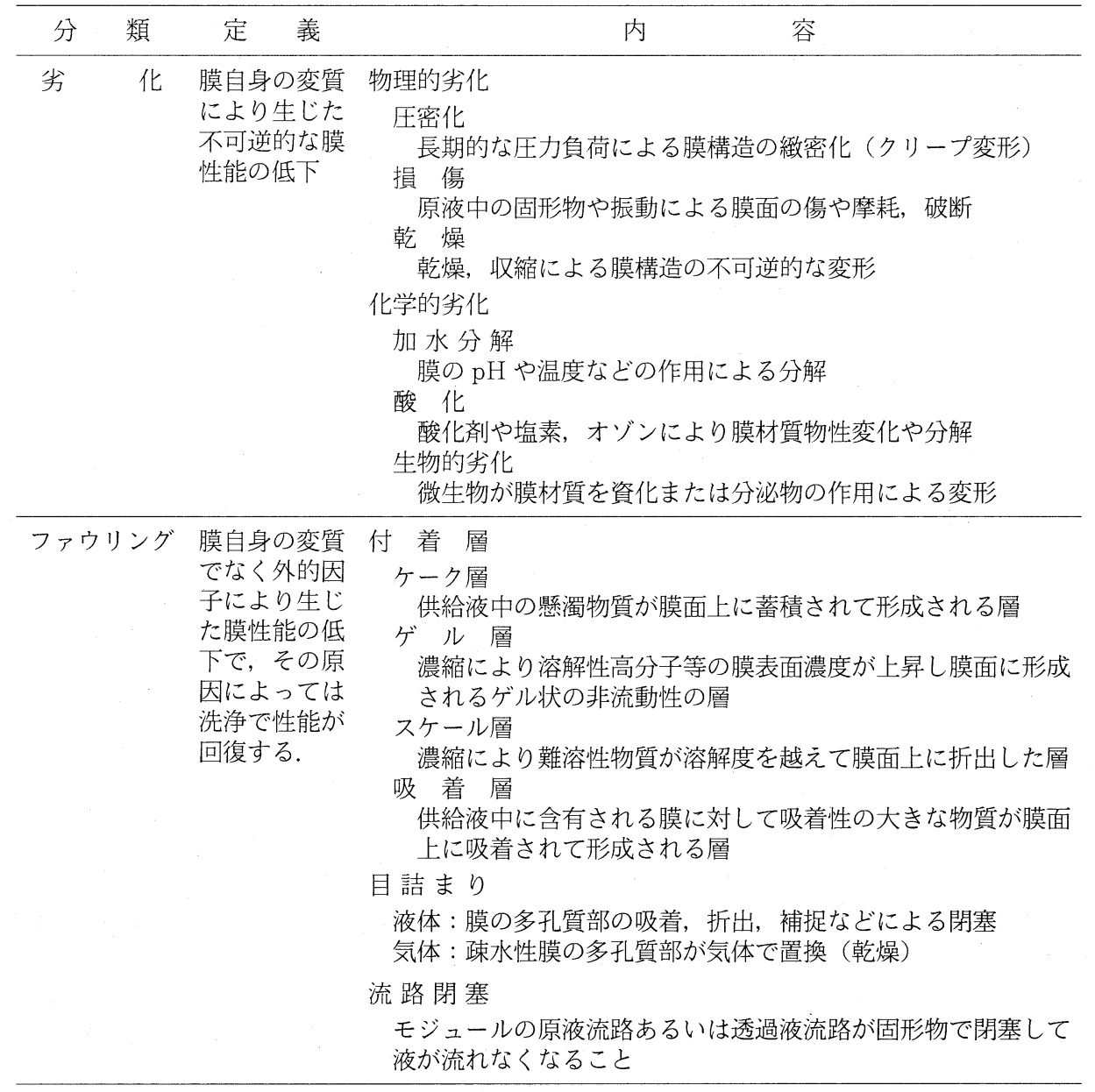

どの分野で採用されている ${ }^{1)}$ 。さらに有機膜・無 機膜を含めて種々の膜素材および膜モジュールの 開発など膜分離技術の発展によって, ますます適 用範用が広がりつつある ${ }^{2.3)}$. 排水処理の分野で は，生物処理と膜分離技術を組み合わせた膜分離 活性污泥法がし尿処理および中水処理で実用化さ れている ${ }^{4,5)}$. 比較的高価な膜が，排水処理の分 野で採用されるのは,

(1) 省スペース化

(2) 省人化

(3) 処理水質の高度化・安定化

(4) 処理プロセスの簡素化による建設費・維持 管理費の低減化
といった膜分離法の特長が理由としてあげられ る。このような膜分離法の特長をうまく生かした 浸漬型セラミック膜処理システムについて以下に 述べる.

\section{2. 膜の劣化とファウリングから見た セラミック膜の特長}

膜はその材質から大きく無機膜と有機膜に分類 される. 現在水処理分野で実用化あるいは実用化 されつつある浸漬型の膜については，無機膜では セラミック製で管状膜エレメントを束ねたものが 主流である. 有機膜では平膜型や中空糸膜型があ 
Table 2 The properties of ceramic membrane

\begin{tabular}{ll}
\hline 材 質 & $\begin{array}{l}\text { アルミナ系セラミック（アルミナ, ム } \\
\text { ライト) }\end{array}$ \\
形 状 & $\begin{array}{l}\text { 管形状 } \\
\text { 分離膜細孔径 }\end{array}$ \\
$0.1 \mu \mathrm{m}$ \\
膜付形状 & 外圧式非対称二層構造 \\
気孔率 & $40 \sim 50 \%$ \\
曲げ強さ & $35 \mathrm{MPa}$ 以上 \\
\hline
\end{tabular}

る. 分離膜を使用すると膜材質やモジュール形状 にかかわらず，多かれ少なかれ膜污染が生じる. 膜污染は通常膜の劣化とファウリングに分けられ る (表 $1^{6)}$ 参照).

これらはいずれも短期的な試験や運転では判定 が難しい内容であることが多い. 劣化は膜自体の 変質により生じた不可逆的な膜性能の低下であ る. 物理的な劣化として压密化, 損傷, 乾燥収縮 などがある. また化学的劣化として加水分解, 酸 化があり, 生物学的劣化として微生物で膜が資化 されるなど, 劣化は有機膜において発生し易い.

ファウリングは外的因子により生じた膜性能の低 下で, その原因によっては洗浄により性能が回復 する. 膜の表面には付着層としてケーク層, ゲル 層, スケール層, 吸着層が形成される. 流路閉塞 は原水之の接液側が, あるいは透過液流路が固形 物で閉塞して液が流れにくくなるなどの状態をさ す.

このような劣化やファウリングを防ぐ，あるい はできるだけ起こさないような対策として膜の適 切な材質, 孔径, 表面処理の選択, さらに膜面お よび透過液側の洗浄, 殺菌などが必要である.こ れらは分離膜・膜モジュールの適用において, 運 転・維持管理性の面で大変重要な要因である ${ }^{6)}$.

膜の污染（劣化とファウリング）から見たセラ ミック膜の特長は以下のようになる.

(1) 物理的・化学的に安定しているので圧密化 や乾燥に強く, 塩素やオゾンなどによる膜材質の 物性変化や分解の心配がない。

(2) 微生物アタック（生物的劣化）を受けない ので微生物による膜材質の資化や分泌物の 作用による変形がない.

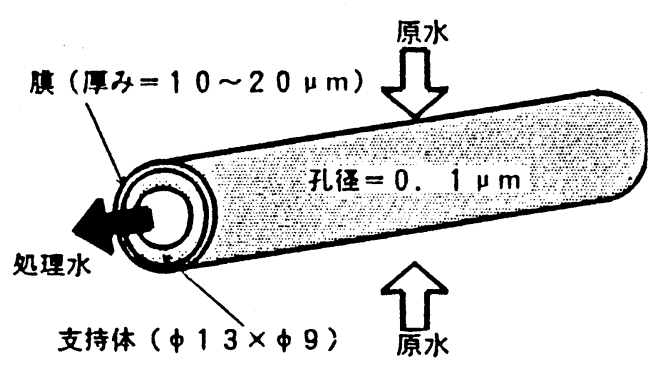

Fig. 1 Schematic illustration of ceramic membrane element

（3）ファウリングを生じても薬品洗浄を強力に おこなえるので性能が回復する.

(4) 長寿命である.

\section{3. セラミック分離膜および 膜モジュールの構造}

表 2 に弊社のセラミック分離膜の主な特性を示 す. 材質はアルミナ系セラミックス, 管形状で分 離膜細孔径は $0.1 \mu \mathrm{m}$ である.気孔率は $40 \sim 50 \%$, 曲げ強さは $35 \mathrm{MPa}$ 以上である. また, 前述の 無機膜の特長を有している.

図 1 にセラミック分離膜のエレメント構造を示 す. セラミック膜は外径 $13 \mathrm{~mm}$, 内径 $9 \mathrm{~mm}$, 肉 厚 $2 \mathrm{~mm}$, 長さ $800 \mathrm{~mm}$ のチューブ状をしてお り, チューブ外側に $10 \sim 20 \mu \mathrm{m}$ の厚みで $0.1 \mu \mathrm{m}$ に制御された膜孔径を有する外圧式非対称二層構 造となっている. 膜の厚みを薄く, 支持体の孔径 を大きくしたことにより，ろ過抵抗を少なくして いる. 膜孔径の分類では, 精密ろ過膜である.

膜の表面之断面の電子顕微鏡写真を図 2 に示 す. 膜の細孔径は素材の微粒子間空隙そのもので あり, 粒子の大きさが小さい程粒子間空隙が小さ く膜孔径が小さくなる.

この膜エレメントをまとめて, 膜の端部を透過 水を集めるためのヘッダーで結合したものを膜モ ジュールとよぶ. 浸漬型セラミック膜モジュール の外観を図 3 に, 仕様を表 3 に示す. 従来のクロ スフロー方式と異なり, 本装置では膜モジュール を槽内に浸漬するので, ケーシングは不要である. このように浸漬型膜モジュールは, 従来の膜モ 


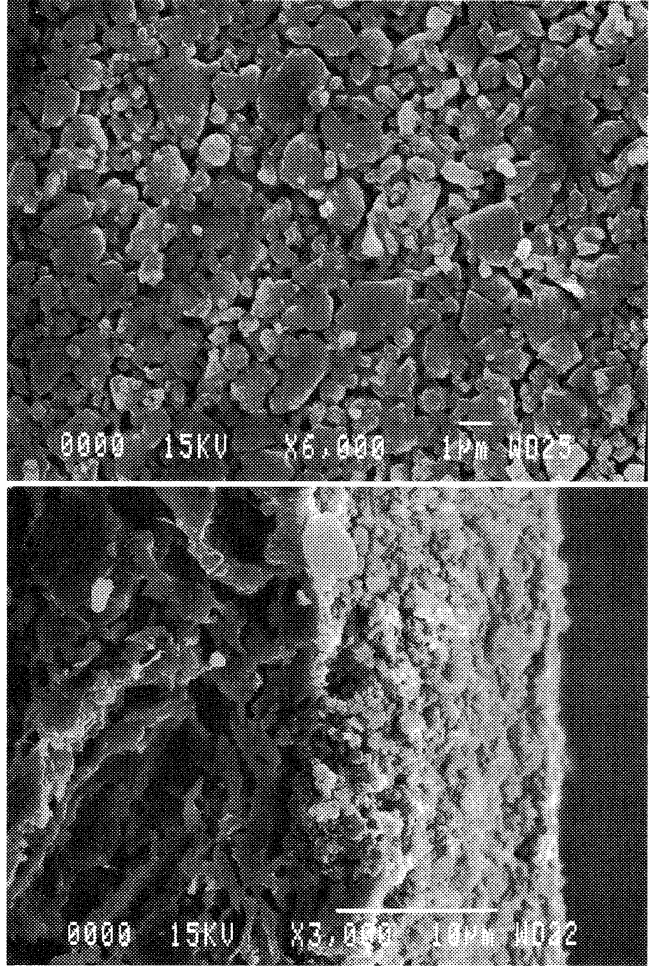

Fig. 2 SEM photographs of surface and cross section of membrane

Table 3 The specification of ceramic membrane module

\begin{tabular}{lr}
\hline \multicolumn{1}{c}{ 項 目 } & KCM-230 \\
\hline 膜面積 $\left(\mathrm{m}^{2}\right)$ & 2.3 \\
寸法 : 高 $(\mathrm{mm})$ & 150 \\
$:$ 幅 $(\mathrm{mm})$ & 258 \\
: 長 $(\mathrm{mm})$ & 873 \\
膜組成 & アルミナ系 \\
膜外径 $(\mathrm{mm})$ & 13 \\
膜内径 $(\mathrm{mm})$ & 9 \\
膜エレメント長 $(\mathrm{mm})$ & 794 \\
膜細孔径 $(\mu \mathrm{m})$ & 0.1 \\
膜厚 $(\mu \mathrm{m})$ & $10 \sim 20$ \\
膜気孔率 $(\%)$ & 40 \\
部材材質 & 硬質塩ビ \\
\hline
\end{tabular}

ジュールとは構造的に大きく異なっている.

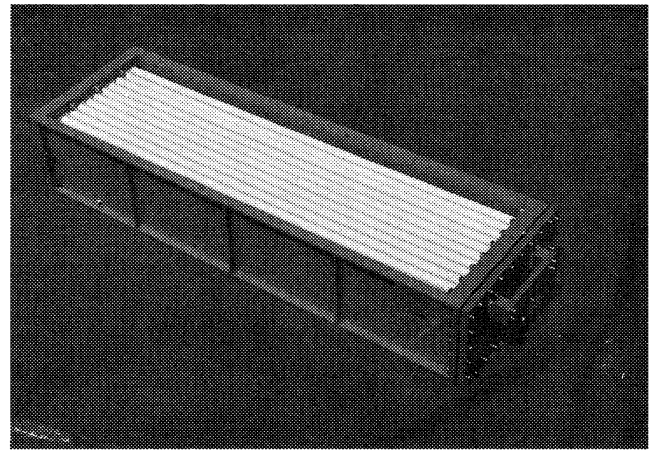

Fig. 3 Ceramic membrane module

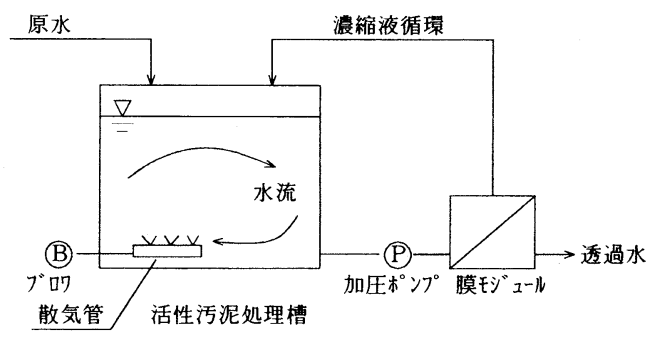

Fig. 4 Flow diagram of convetional activated Sludge/membrane process

\section{4. 浸漬型膜分離活性污泥法の原理亡装置}

図 4 に従来の加圧クロスフロー膜分離処理シス テムのフロー図を示す．この加圧クロスフロー分 離法は, 最も古くから実用化されている膜分離方 法で, 反応槽の後段に膜分離装置が設置され, 被 処理液をポンプで膜分離装置に压送する.この時, 膜を透過する透過液の何 10 倍もの被処理液を循 環しなければならず，さらに高圧を必要とするた め所要動力が大きく，また装置的にコンパクトで ないといった欠点がある.

筆者らは, セラミック膜モジュールを反応槽内 に浸漬し，その下部から曝気を行い気泡の上昇擋 拌流を膜の表面に与えることにより，セラミック 膜外面に生じるケーク層等の付着物を除去し, 安 定したろ過が行える浸漬型膜処理方法を開発し た. 浸漬型膜処理方法は, もともとメタン発酵液 の分離を発端としており ${ }^{7 \sim 9)}$, それを活性污泥 法等 ${ }^{10.11)}$ に発展させたものである. 図 5 に浸漬 


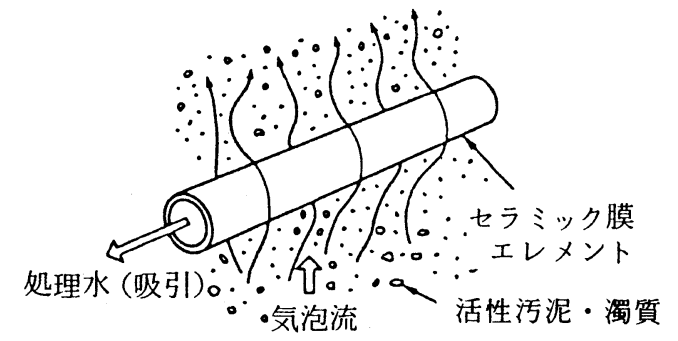

Fig. 5 Schematic illustration of tank submerged type ceramic membrane method

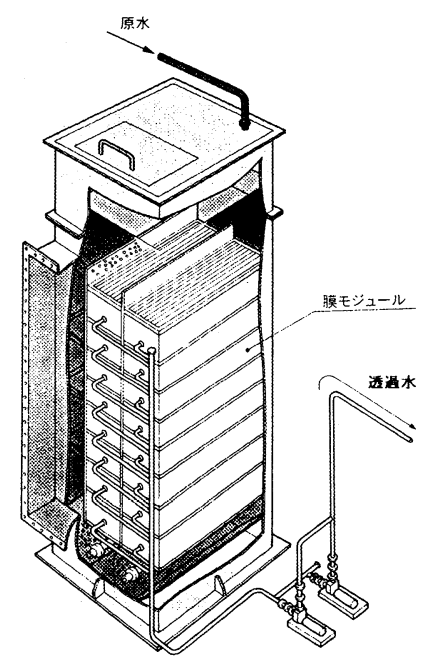

Fig. 7 Schematic illustration of BIOREM

型膜処理の原理を, 図 6 に浸漬型膜処理システム のフロー図を示す。

ろ過水は水圧と極めて小さい減压とにより得ら れる. また，反応槽内では活性污泥処理の反応も 並行して行われるので, 省エネルギーでコンパク 卜な装置となる. 図 7 に浸漬型膜処理装置の構造 忷を示す.膜モジュールは多段に積層でき, スケー ルアップも容易な装置である。

活性污泥法と浸漬型膜処理を組み合わせたもの を BIOREM, 凝集法と浸漬型膜処理を組み合わ せたものをFILCERA と称している.

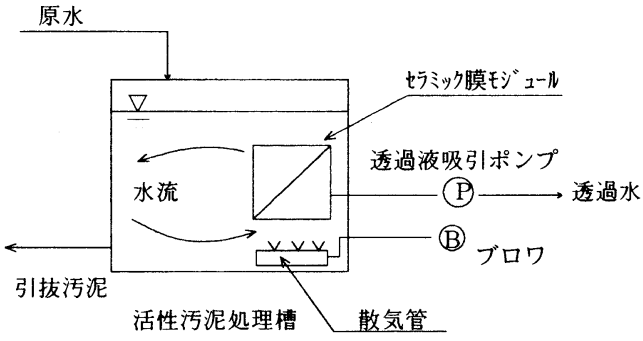

Fig. 6 Flow diagram of BIOREM

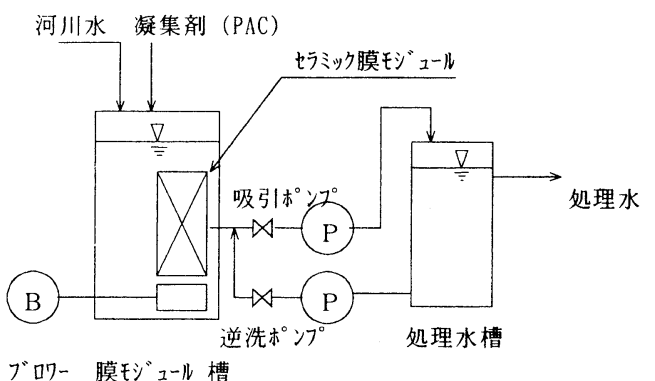

Fig. 8 Schematic illustration of FILCERA

\section{5. システム適用例}

凝集法と浸漬型膜処理を組合せた膜処理の 1 例 として浄水処理への適用がある．従来は凝集混和 池, 沈殿池, 砂ろ過の組合せで処理されていたが, 浸漬型膜処理技術では一槽でこれらの働きをおこ なえるのでプロセスの簡略化ができる，一方，活 性污泥法と組合せた膜処理システムは中水処理,

下水処理，小規模下水・合併浄化槽，農村集落排 水処理そして有機系の産業廃水処理などが対象と なる. 従来これらの処理は曝気槽, 沈殿池, 砂ろ 過の組合せで処理されていたが，浸漬型膜処理技 術では曝気槽内に膜を設置するだけなのでプロセ スのシンプル化が図れる.

\section{1 浄水処理システム}

\subsection{1 システムの内容}

装置のフロー図を図 8 に示す。凝集剤を注入し てマイクロフロックを形成させた原水（河川表流 水）を膜モジュール槽に導き, 膜分離によってマ イクロフロックを固液分離し, 処理水を得る. 
Teble 4 The analysis of raw water and filtrate

\begin{tabular}{|c|c|c|}
\hline 項 & 水 & 膜万過水 \\
\hline 濁度（度） & 15.5 & 0.01 \\
\hline 色度（度） ～～～～～ & 9 & 4 \\
\hline $\mathrm{KMnO}_{4}$ 消費量 $(\mathrm{mg} / \mathrm{l})$ & 7.6 & 2.8 \\
\hline $\mathrm{E}_{260}(50 \mathrm{~mm}$ cell $)$ & 0.174 & 0.165 \\
\hline $\mathrm{NH}_{4}-\mathrm{N}(\mathrm{mg} / \mathrm{l})$ & 0.05 & 0.02 \\
\hline 総マンガン $(\mathrm{mg} / l)$ & 0.052 & 0.005 以下 \\
\hline 総鉄 $(\mathrm{mg} / l)$ & 0.99 & 0.01 以下 \\
\hline 溶性ケイ酸 $(\mathrm{mg} / \mathrm{l})$ & 23.1 & 21.9 \\
\hline 一般細菌（個/ml） & 32,000 & 56 \\
\hline 大腸菌群（個/ml） & 379 & 0 \\
\hline T-THMFP $(\mathrm{mg} / l)^{* 1}$ & 0.045 & 0.033 \\
\hline $\mathrm{DOC}[0.1 \mu \mathrm{m}](\mathrm{mg} / l)^{* 1}$ & 1.3 & 1.2 \\
\hline 臭気強度 $(\mathrm{TON})^{* 2}$ & 37 & 5.9 \\
\hline
\end{tabular}

※1 sample number : 6

${ }^{\star 2}$ sample number : 3 others : 26

Table 5 The analysis of raw water and filtrate

\begin{tabular}{lrrrrrr}
\hline & & \multicolumn{2}{c}{ 夏 } & & \multicolumn{2}{c}{ 冬 } \\
\cline { 7 - 8 } & & 原水 & 透過水 & & 原水 & 透過水 \\
\hline 水温 & $\left({ }^{\circ} \mathrm{C}\right)$ & 26.0 & 26.0 & & 15.0 & 15.0 \\
$\mathrm{pH}$ & $(-)$ & 6.5 & 7.1 & & 6.8 & 7.2 \\
$\mathrm{SS}$ & $(\mathrm{mg} / l)$ & 25 & 1 以下 & & 35.0 & 1 以下 \\
CODMn & $(\mathrm{mg} / l)$ & 39.2 & 4.7 & & 46.0 & 7.8 \\
$\mathrm{BOD}$ & $(\mathrm{mg} / l)$ & 85 & 2 以下 & & 112 & 2 以下 \\
$\mathrm{T}-\mathrm{N}$ & $(\mathrm{mg} / l)$ & 11.5 & 5.2 & & 6.1 & 1.9 \\
$\mathrm{~T}-\mathrm{P}$ & $(\mathrm{mg} / l)$ & 1.23 & 0.65 & & 1.42 & 0.7 \\
MLSS & $(\mathrm{mg} / l)$ & \multicolumn{2}{c}{11,550} & & \multicolumn{2}{c}{12,500} \\
\hline
\end{tabular}

\section{1.2 運転結果}

$\mathrm{MAC} 21$ 計画（膜利用型新浄水システム開発研 究）実証試験の結果 ${ }^{12)}$ を例として示す.

(1) 透過流束の安定性

本システムは定量ろ過のため, 膜ろ過の進行に 伴い吸引圧力が变化する. 膜透過流束は $1.0 \mathrm{~m}^{3} /$ $\mathrm{m}^{2} \bullet \mathrm{d}$ に設定したが, 約 5 力月にわたって $10 \mathrm{kPa}$ 前後の低い膜間差圧で安定した運転を継続でき た.

(2) 処理性能

表 4 に本システムによる処理性能結果を示す. 濁度, 鉄, マンガン, 大腸菌は完全に阻止できて

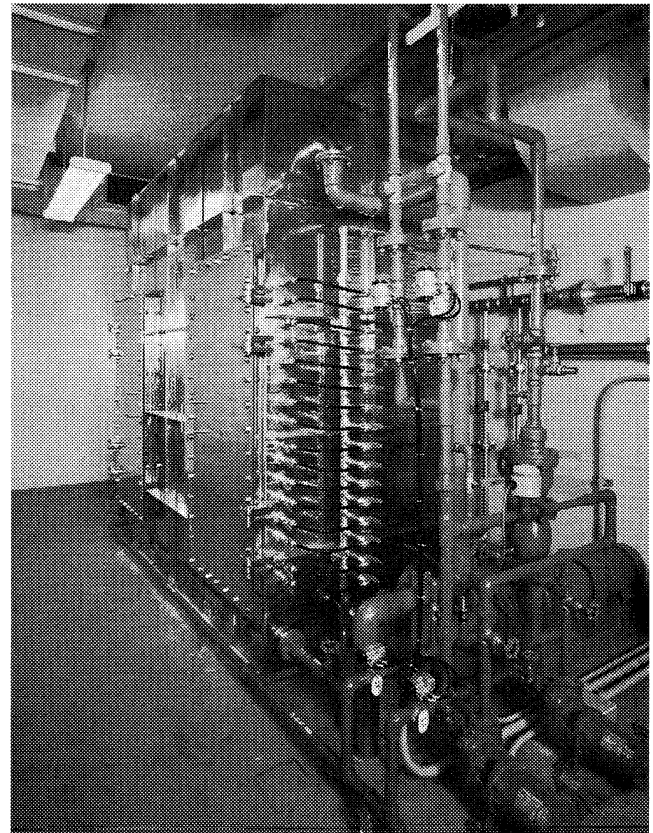

Fig. 9 View of the BIOREM for water reuse

いる. 一方, 精密ろ過膜であるので, 溶解成分 (DOC, $\mathrm{E}_{260}$, 溶性ケイ酸) の除去率は低かった. このシステムは本来固液分離を目的としたもので あるが, 生物処理機能を有していることにより, アンモニア性窒素の除去ができていることが確認 された。

\section{1.3 高度処理 MAC21}

MAC 21 計画を発展させた膜利用型新高度浄 水技術開発研究（呼称高度処理 MAC 21）が平 成 6 年度から 3 年間, 通常の浄水処理では効率的 に除去できないトリハロメタン前駆物質, 微量化 学物質, 異臭味さらにはウイルス等の除去をも可 能にする, より高度な膜ろ過浄水処理システムの 確立を目的として研究が進められている ${ }^{13)}$. 弊 社も高度処理 MAC 21 に参画し鋭意研究中であ る.

\section{2 中水処理システム（ビル排水の再利用処} 理)

\section{2 .1 システムの内容}

装置の外観を図 9 に示す. 原水は弊社本社ビル 


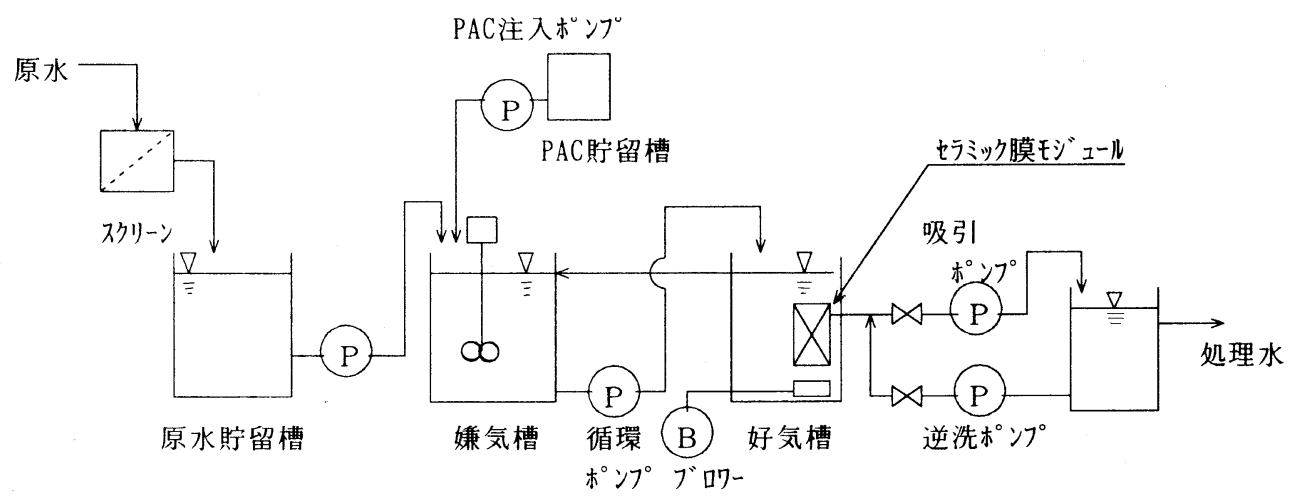

Fig. 10 Flow diagram of pilot plant for domestic sewage

の厨房排水を含む雑排水であり，処理規模は 40 $\mathrm{m}^{3}$ /日である。曝気槽内は実容量 $4.8 \mathrm{~m}^{3}$ でその 中へ膜モジュールを浸漬し, 膜モジュール下部よ り空気を曝気して膜モジュール部への曝気槽混合 液の供給と微生物への酸素供給とを行っている. 曝気槽内には，外圧型セラミック膜モジュールが 24 台挿入されており, 万過液側から吸引し, 所 定量処理している。 また定期的に処理水による逆 洗を行っている.

\section{2 .2 運転結果}

本装置は平成元年 7 月の運転開始以来順調に稼 動し, 処理水は水洗便所洗浄用水, 修景用の滝用 水等, 中水として再利用されている.

(1) 処理結果

表 5 に夏および冬の処理結果の例を示す. 処理 水 COD はいずれも $4.7 \sim 7.8 \mathrm{mg} / l$ と常時除去率 $80 \%$ 以上であり，BOD は $2 \mathrm{mg} / l$ 以下を示し除 去率 $95 \%$ 以上であった. 処理水の透視度は 100 $\mathrm{cm}$ 以上であり, SS は検出されていない.この ように処理水質は季節的変動はなく安定してい る. $\mathrm{NH}_{4}-\mathrm{N}$ (アンモニア性窒素) は処理水には ほとんど検出されず，硝化反応はほほ $100 \%$ 進行 した. また T-N (総窒素) は 54.8〜 68.9\% 除去 され, T-P（総リン化合物）の除去率は 48.1 $50.7 \%$ であった。 大腸菌数は陰性 $/ \mathrm{ml}$, 一般細菌 は $2.3 \times 10^{2} / \mathrm{ml}$ と低く, その他の水質項目から も本法による処理は再利用水として水質基準を充 分に満足している.
(2) 膜透過性能

逆洗之曝気による膜面洗浄により透過流束は $0.7 \mathrm{~m}^{3} / \mathrm{m}^{2}$ ・日を保ち, 長時間安定している. 薬 品洗浄は 6 力月に 1 回程度の頻度でよい.

(3) 所要動力

周辺の機器（ブロワ，吸引ポンプ）を合わせた 消費電力は, 約 $1 \mathrm{kw} \cdot \mathrm{h} / \mathrm{m}^{3}$ となり従来の膜利用 活性污泥法より省エネ型の装置である.

\section{3 生活排水処理}

\section{3.1 システムの内容}

実証試験として硝化液循環脱窒法による脱窒機 能と PAC（ポリ塩化アルミ）添加によるリン除 去機能を付加させた膜分離活性污泥処理法の生活 排水系への適用を行い, 日本建築センターの一般 性能評定ならびに建設大臣認定を得た（処理対象 人員 $201 \sim 5,000$ 人, 日平均処理污水量 $40.2 \sim$ $1,000 \mathrm{~m}^{3}$ /日). 図 10 に実証試験装置概略図を示 す. 設計水量は $10 \mathrm{~m}^{3} /$ 日で, 原水は住宅団地下 水の荒目スクリーン $(30 \mathrm{~mm})$ 通過水とし, 微細 目スクリーン $(1 \mathrm{~mm})$ を通して嫌気槽に流入さ せた，好気槽では膜モジュールの下部散気管から 空気を散気し, 膜表面の洗浄と微生物への酸素供 給を同時に行った.

\section{3.2 運転結果}

(1) 透過水量

膜モジュールの薬品洗浄なしに 1 年間以上安定 して所定の透過水量を確保できた。 本システムは 
鳴上・塩山 : 浸漬型セラミック膜処理システムの開発と応用

Table 6 The analysis of influent and effluent

\begin{tabular}{lccc}
\hline & & 原 水 & 処理水 \\
\cline { 3 - 4 } & & 平均 (最小〜最大) & 平均 (最小〜最大) \\
\hline 水温 & $\left({ }^{\circ} \mathrm{C}\right)$ & $-(13.9 \sim 32.7)$ & $-(15.7 \sim 35.0)$ \\
$\mathrm{pH}$ & $(-)$ & $7.44(6.7 \sim 8.0)$ & $7.02(6.8 \sim 7.3)$ \\
$\mathrm{SS}$ & $(\mathrm{mg} / \mathrm{l})$ & $152(96 \sim 229)$ & 1 以下 $(-)$ \\
$\mathrm{BOD}$ & $(\mathrm{mg} / \mathrm{l})$ & $192(146 \sim 286)$ & 5 以下 $(-)$ \\
$\mathrm{COD}$ & $(\mathrm{mg} / \mathrm{l})$ & $91.9(75.9 \sim 113)$ & $7.51(4.1 \sim 19.4)$ \\
$\mathrm{T}-\mathrm{N}$ & $(\mathrm{mg} / \mathrm{l})$ & $46.6(35 \sim 63)$ & $7.44(5.2 \sim 9.8)$ \\
$\mathrm{NH}_{4}-\mathrm{N}$ & $(\mathrm{mg} / \mathrm{l})$ & $39.0(26.8 \sim 52.2)$ & 0.3 以下 $(-)$ \\
$\mathrm{NO}_{2}-\mathrm{N}$ & $(\mathrm{mg} / \mathrm{l})$ & 0.01 以下 $(-)$ & 0.01 以下 $(-)$ \\
$\mathrm{NO}_{3}-\mathrm{N}$ & $(\mathrm{mg} / \mathrm{l})$ & 0.1 以下 $(-)$ & $6.16(3.9 \sim 9.0)$ \\
$\mathrm{T}_{-} \mathrm{P}$ & $(\mathrm{mg} / l)$ & $5.22(3.1 \sim 7.0)$ & 0.2 以下 $(-)$ \\
\hline
\end{tabular}

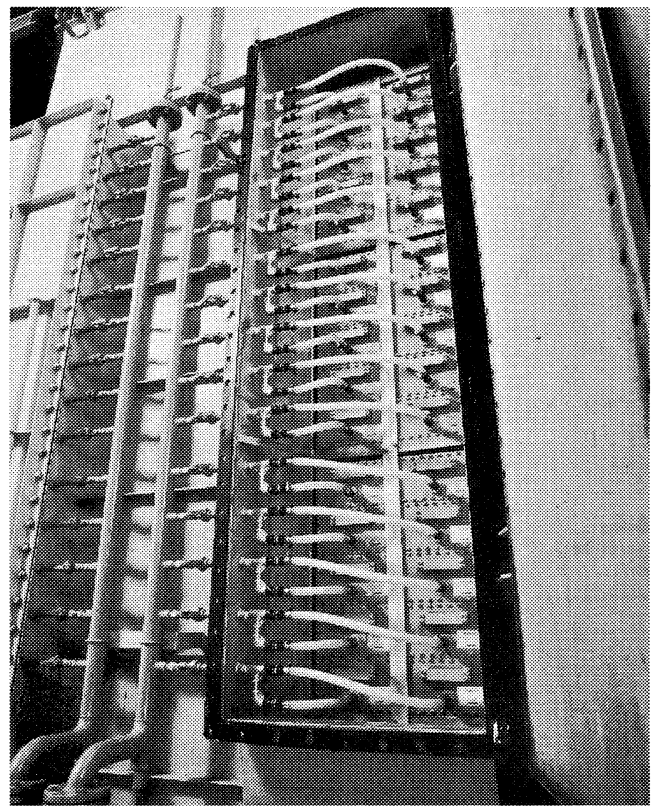

Fig. 11 The $100 \mathrm{~m}^{3} /$ day BIOREM system for domestic sewage

安定した処理が可能であり, 膜洗浄等のメンテナ ンスが簡単で使いやすい優れたシステムであると の知見が得られた。

(2) 処理性能

表 6 に本試験で得られた処理水の水質分析結果 を示す. 原水濃度は $\mathrm{SS} 100 \sim 230 \mathrm{mg} / l, \mathrm{BOD}=$ $150 \sim 290 \mathrm{mg} / l, \mathrm{~T}-\mathrm{N}=35 \sim 63 \mathrm{mg} / l, \mathrm{~T}-\mathrm{P}=3.1 \sim$
Table 7 Fouling Index of BIOREM and FILCERA

\begin{tabular}{ccc}
\hline FI 値 & BIOREM & FILCERA \\
\hline 平均値 & 2.33 & 1.27 \\
最大值 & 3.50 & 3.11 \\
最小値 & 0.94 & 0.25 \\
\hline
\end{tabular}

$7 \mathrm{mg} / l$ であったが処理水濃度は SS については 精密万過膜処理のため検出限界 $(1 \mathrm{mg} / l)$ 以下之 なり, BOD は $5 \mathrm{mg} / l$ 以下, $\mathrm{T}-\mathrm{N}$ は $10 \mathrm{mg} / l$ 以 下となった。リン除去については原水 $\mathrm{T}-\mathrm{P}$ に対 してモル比で約 1.5 倍の $\mathrm{Al}$ を $\mathrm{PAC}$ として添加 しているため, 処理水 $\mathrm{T}-\mathrm{P}$ は $0.2 \mathrm{mg} / \mathrm{l}$ 以下とな り, 非常に良好な処理水が安定して得られた。

\section{3 .3 実設備への適用}

日本建築センターの一般性能評定に先立ち個別 性能評定を受けて $100 \mathrm{~m}^{3}$ /日の合併浄化槽設備 を兵庫県姫路市内に納入している (図 11 参照).

\section{4 廃水の再利用への応用}

昨年は好天が続き日本各地で渴水状態が続い た。このような状況では廃水を低コストで再利用 できれば水の安定供給の一助となる. 周知のよう に RO 膜は飲料水等の良質の水を生産できるが, 前処理が繁雑でスペース・コスト・維持管理の面 から廃水再利用の用途は限られている。一般に ROの前処理水の水質は FI (Fouling Index) $<4$ が求められる. BIOREM や FILCERA などの 


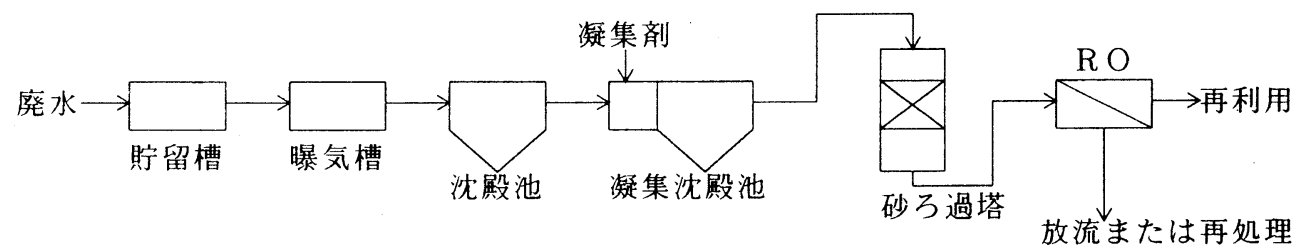

Fig. 12 Flow diagram of conventional RO system for water reuse

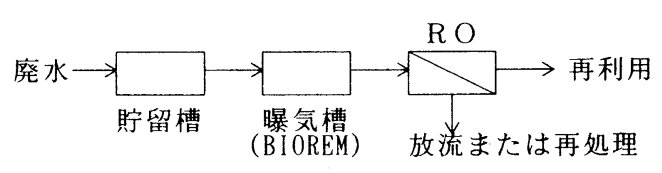

Fig. 13 Flow diagram of BIOREM/RO sys- $^{-}$ tem for water reuse

セラミックろ過では膜の公称孔径が $0.1 \mu \mathrm{m}$ のた め, 処理水の SS は不検出となる. 表 7 に BIOREM と FILCERA の FI 測定值の 1 例を示す. 図 12 に従来の RO システムのフローを, 図 13 に BIOREM とRO を組み合わせた再利用システム のフローを示す. セラミック膜を用いた水処理シ ステムはこのようにシステムが簡略化され， ス ペース・コスト・維持管理の面で有力なシステム であるといえる.

\section{6. おわりに}

セラミック膜分離装置と曝気槽や反応槽等を一 体化した浸漬型膜処理システムは浄水処理, 下水 処理, 中水処理, 生活排水処理, 廃水再利用など に有効な処理システムである. 省スペース化, 水 質の高度化・安定化, 維持管理面など優れたシス テムであることも明らかである.

膜技術は分離性能に優れていることは, 古くか ら明らかにされているが，実際的な適用において は, 膜の劣化とファウリング対策としての膜の選 定, 膜の洗浄法, 膜寿命, スケールアップ, 透過 流束と経済性などが検討課題である，セラミック 分離膜とその処理システムは, 長寿命, 耐薬品性 なども加わって総合的に優れている.

クボタでは，ここに紹介した膜分離技術をはじ
めとして，各種の排水処理システムおよび造水・ 用水用途としてより高い機能を付加した高品質処 理システムの開発・実用化に取り組んでいる.

\section{文 献}

1）化学工学会：「膜分離工学一その現状と工業的応 用一」化学工業社 p.1 (1989)

2) 宮内潔, 坂本浩一, 高比良正器, 鳴上善久: 第 44 回全国水道研究発表会講演集 p.423 (1993)

3) 山本康次, 奥村早代子, 土井均, 木兽祥秋, 鳴上 善久, 松田恒男: 用水之廃水, 36 (2) p. 29 (1994)

4）真柄泰基 : 環境技術, 16 (12) p. 798 (1987)

5) 徳島幹治, 鳴上善久, 松田恒男: 化学工学会 57 年 会第 1 分冊 p.46 (1992)

6) 小山清, 西村正人：水処理技術，33（2）p.33 (1992)

7）河杉忠昭, 山県昌継, 鳴上善久, 岡本恭典, 塩山 昌彦: 第 2 回生物膜法研究シンポジウム講演集 $p$. 57 (1987)

8) E. Kayawake, Y. Narukami, K. Tokushima, T. Ozaki, M. Yamagata : Proc ICOM '90 p. 1128 (1990)

9) E. Kayawake, Y. Narukami, M. Yamagata : J. Fermen. \& Bioeng 71 (2) p. 122 (1991)

10）山県昌継, 鳴上善久, 柏分英介, 川西敏雄, 松田 恒男: 第 27 回下水道研究発表会講演集 p. 299 (1990)

11）柏分英介, 山県昌継, 鳴上善久, 川西敏雄, 堤行 彦：第 41 回全国水道研究発表会講演集 p. 197 (1990)

12）川西敏雄, 横山繁樹, 塩山昌彦, 堤行彦 : 第 44 回 全国水道研究発表会講演集 p.357 (1993)

13) T. Kawanishi, M. Ide, H. Akazawa, O. Tanaka : 4th Japan-U.S. Governmental Conference on Drinking Water Quality Management, Osaka, Japan p. 11-B-1(1994)

（受付 1995 年 7 月 5 日） 